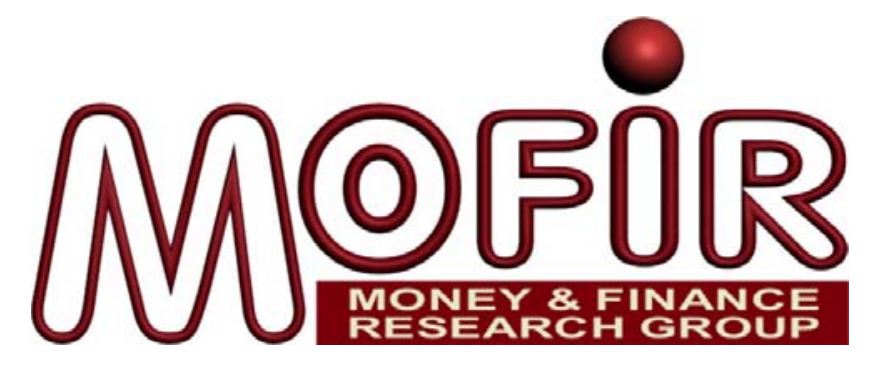

\title{
GLOBAL BANKING AND LOCAL MARKETS
}

\author{
PIETRO ALESSANDRINI \\ Università Politecnica delle Marche, Department of Economics \\ MoFiR
}

ANDREA F. PRESBITERO

Università Politecnica delle Marche, Department of Economics MoFiR

CeMaFiR

ALBERTO ZAZZARO

Università Politecnica delle Marche, Department of Economics MoFiR

MoFiR working paper $n^{\circ} 4$

October 2008 


\title{
Global Banking and Local Markets
}

\author{
Pietro Alessandrini, Andrea F. Presbitero and Alberto Zazzaro \\ Department of Economics \\ Università Politecnica delle Marche - Ancona (Italy) \\ and \\ Money and Finance Research group (MoFiR)
}

\begin{abstract}
In the early 1990s, a widely-shared opinion among scholars and practitioners was that the importance of physical proximity between banks and borrowers would be doomed to drastically decrease over time and, put in extreme terms, the end of banking geography would become a real possibility. However, the empirical evidence show an unrelenting importance of local credit markets for small borrowers and local economic development. In the paper, we selectively review the literature on the real effects of bank consolidation and produce new evidence on the role of headquarter-to-branch functional distance on relationship lending.
\end{abstract}

JEL Codes: G21, G34, R12, R51

Keywords: Global Banking; Local Banking Development; Functional Distance

\section{Introduction}

In the early 1990s, a widely-shared opinion among scholars and practitioners was that deregulation, advancements in information technology and financial innovations would make banking activity ever more transaction-oriented, by including private equity activities, loan securitisation, asset management, asset-based and credit-scored lending, insurance products and so on. A natural consequence of this trend would be the expansion of banks on a global scale both geographically and in terms of products supplied. Few big, well managed, global players, would be able to offer standardised products in many different countries, at the same time without suffering from competitive disadvantage in lending to small and medium enterprises (SMEs) and other informationally opaque borrowers. Some critical voices on global banking warned against the relatively high costs that the consolidation and geographical agglomeration of bank decisional centres would generate for peripheral regions and small local firms (Chick and 
Dow 1988, Branson 1990; Martin, 1994; Alessandrini and Zazzaro 1999) ${ }^{1}$. However, according to the common wisdom, the importance of physical proximity between banks and borrowers would be doomed to drastically decrease over time and, put in extreme terms, "the end of financial geography", would become a real possibility.

Moving from these premises many banks' board of governors, across all countries, accepted global banking principles, starting an unprecedented campaign of mergers and acquisitions (M\&As) in search of scale/scope economies (apart from private managerial benefits), encouraged in this also by various forms of explicit and implicit subsidies handed out by national governments with the goal of creating national champions. Therefore, following a sort of selffulfilling prophecy, the profound reorganization experienced by the banking industry in the following fifteen years has lent further support to the global banking view. Accordingly, nowadays the average size of banks looks definitely bigger in almost every country, their organization is much more complex, and the product and geographical markets they serve are wider and wider.

However, two further stylized facts have emerged, throwing doubt on the hegemony of global banking and revealing an unrelenting importance of local markets and small borrowers. First, the bank consolidation process has been mainly domestic: although the number of bank cross-border M\&As is increasing, they are still relatively few especially if compared with what has happened in other sectors (Pozzolo 2009). This clearly indicates that geographical, cultural and regulatory barriers still maintain a great importance in banking (Buch and DeLong 2008). Second, the bank consolidation pattern has often been accompanied by an opposite diffusion trend in branch networks and distribution channels, confirming that bank competition continues to be played out in the field of physical proximity to local borrowers (De Young et al. 2004; Alessandrini, Presbitero and Zazzaro 2008a).

From this consolidation-diffusion trend several important questions have arisen to which economists and geographers are devoting a great amount of research effort. In the era of global banking, is relationship lending still important? Has the structure of a local banking system any real effect on the local economy? Does distance matter in bank-firm relationships, (and if so, what kind of distance)? What are its effects on credit availability to small firms and innovative projects?

\footnotetext{
${ }^{1}$ In the words of Klagge and Martin (2005, p. 388), "the argument [was] that the spatial structure of the financial system can influence the supply of finance to firms, and thereby contribute to uneven regional development. The implication is that the more centralized is a country's financial system, the more difficult it will be for firms - and especially small firms - in peripheral regions to access funds".

2 This was the thought-provoking title of O'Brien's book (1992) that critically opened the discussion on the effects of technological, financial and regulatory innovations on the geography of finance.
} 
In this paper we review the main empirical evidence on these questions and produce some new results by focusing on the Italian experience. Italy is an important and representative case study for at least three reasons. First, the consolidation process and the changes in the ownership structure of the banking industry at the local level have been particularly intense during the last twenty years. Second, the weight of micro and small firms in the country's economy is massive. Third, in Italy regional economic and social disparities are very pronounced and long-lasting. Much of the literature on the macro-real effects of bank M\&As has focused on the consequences that the increased size of banks has on the availability of external finance for small and medium local firms. The standard argument is that large banks face a competitive disadvantage in financing informational opaque borrowers because of organizational diseconomies which makes the screening, underwriting and monitoring of soft-information-intensive business projects disproportionately costly (Berger et al. 1998). This would make the larger banks resulting from M\&As shy away from small business lending and relation-based transactions. However, as Berger and Udell (2006) cogently argued, the sharp distinction between arm's length lending for informationally transparent borrowers and relationship lending for opaque borrowers is too simplistic. A number of lending technologies to harden soft information, like credit scoring or leasing, have been developed and widely deployed by large institutions to funding opaque businesses (Berger, Rosen and Udell 2007, Udell 2009). Moreover, due to the greater portfolio diversification, large banks can be less risk-averse and hence more inclined to finance new initiatives and innovative projects. In empirical terms, the available findings are at least mixed, showing that the overall effects of M\&As on small business lending are heterogeneous with respect to the kind of credit institutions involved and depend on the reaction by incumbent and new banks, which could fill the gap left by acquired banks.

A new strand of banking literature has shifted the emphasis onto the geography of the banking industry and the spatial organization of banks, while considering the notion of distance as the critical interpretative key to address the global-local issue in credit markets ${ }^{3}$. Within this line of research, our approach to the spatial organization of a banking system is based on distinguishing two kind of distances.

The first one is operational distance, which measures the external distance between banks' lending branches and local borrowers. The increased diffusion of banking structures and distributive channels has reduced such a distance, whose effects on the bank-firm relationship are controversial. On the one hand, lender-borrower operational distance hampers the gathering of soft information and weakens relationship lending, to the detriment of informationally opaque SMEs. On the other hand, operational distance could reduce the bank's market power with

\footnotetext{
${ }^{3}$ The articles collected in Alessandrini, Fratianni and Zazzaro (2009) provide a wide overview of this literature.
} 
beneficial consequences on credit conditions and on the availability of finance to small firms and innovative projects.

A second fundamental distance that affects bank-firm relationships is functional distance, which measures the internal distance between a local branch and the decisional centre of the parent bank (typically the bank headquarter). On average, the bank consolidation process has greatly increased this distance, whose effect is to heighten organizational frictions and make functionally distant branches shy away from lending to soft-information-intensive borrowers. Size being equal, there are a number of problems connected with the distance between local branches, where loan officers collect information on borrowers, and headquarters, where the lending policy is set, loan reviewers report and the career of local managers is decided. For example, the greater the functional distance from a local market, the lower the reliability of communication and trust between local loan officers and bank's central managers and the greater the cost of processing information on opaque borrowers collected at the local branch.

The empirical evidence we present in this paper is broadly consistent with the hypothesis that functional distance of the local banking system from the local economy increases the probability of SMEs of being credit rationed and decreases their capacity to introduce innovations and borrowing on relational basis.

The rest of the paper proceeds as follows. In Section 2, we summarize the main changes occurring in the structure of the Italian banking system during the last twenty years, compare them with the experience of other European countries and introduce the notions of operational and functional distances. In Section 3, we review the empirical evidence on the impact of the bank M\&As on credit allocation to SMEs. In Section 4 and 5, we discuss our empirical results on the effect of increased functional distance on bank-firm relationships, with particular reference to credit access, innovation financing, and relationship lending. Section 6 concludes.

\section{The changing structure of the Italian banking industry}

\subsection{A comparison with Europe}

Albeit with different degrees of intensity, the bank consolidation process has touched every European country. From 1990 to 2004 there were 2,734 M\&A deals involving bank institutions in EU-15 area countries, of which more than 50\% were domestic and within the banking industry (Dermine 2006). Consolidation accelerated after the introduction of the single currency, further reducing the number of credit institutions by 20 per cent (from 8,637 in 1997 to 6,130 in 2006; ECB 2004, 2007) and, especially since 2005, it has involved important cross-border M\&As.

While the average size of banks has increased almost everywhere in Europe, the relative importance that the banking industry assumes in the domestic economy varies greatly across 
Europe (Figure 1). For example, the frequently cited small size of the Italian credit market seems more related to the overall weight of the banking system in the economy than to bank size, as shown by the ratio of banking assets to GDP, which is well below the values registered in other European countries. By contrast, the considerable increase in branch openings experienced in Italy since deregulation in the 1990s has significantly reduced the lag in terms of branch density with respect to the Monetary Union. In this respect, the trend of branches per inhabitants shows a high variability across European countries, being higher and rising in France and Spain and lower and declining in Germany, the Netherlands and the United Kingdom, where impersonal communication and distribution channels, such as automated transfer machines or internet banking, are more widespread and complement the more traditional branch network ${ }^{4}$.

[Insert Figure 1 and 2]

Also the effects of M\&As on the degree of market concentration has been very dissimilar in Europe. The Herfindahl index measured in terms of total assets strongly increased in France, the Netherlands, Spain and the United Kingdom. By contrast, it remains very low in Germany and Italy, which share a large presence of mutual banks with local vocation (Figure 2). Finally, as a result of some relevant cross-border operations, the degree of internationalization of the Italian banking system has significantly increased, with the assets of foreign branches and subsidiaries reaching $14 \%$ of total assets in 2006. This ratio is now higher than in France, Germany and Spain and is almost similar to the Monetary Union average (Figure 3).

[nsert Figure 3]

\subsection{The spatial organization of banking industry in Italy}

The deregulation of the early 1990s, the crisis of the major credit institutions operating in southern Italy and the search for a national champion has produced a dramatic change in the geography of banking industry in Italy. On the whole, the total number of banks has gradually decreased, dropping from 1,156 in 1990 to 785 banks in 2005. While mutual banks the consolidation has proceeded by mergers, for the other banks the predominant form of consolidation has been the acquisition of capital (Table 1).

The consolidation process has also shown a high degree of spatial heterogeneity across the wellknown Italian North-South divide. Without considering mutual banks, the Centre-North has preserved a large number of independent banks (108 in 2005 versus 141 in 1995), and there has been a significant increase in the number of credit institutions belonging to bank groups. By contrast, the number of independent banks headquartered in economically less advanced

\footnotetext{
${ }^{4}$ In these countries, respectively, 32, 59 and 28 per cent of individuals older than 16 years used internet banking at least once during a period of three months in 2006, compared to the EU-15 average of 24 per cent (ECB 2007).
} 
southern regions (one third of the country in terms of population) diminished to just 8 in 2008 (versus 56 in 1995), while the number of southern banks affiliated to centre-northern groups, after an initial increase, has remained almost stable.

\section{[nsert Table 1]}

The process of mergers and acquisitions has gone hand in hand with the rapid spatial diffusion of the branch network throughout the country. The number of branches has steadily increased over time getting to serve, on average, less than 2,000 inhabitants per branch, even if the presence of bank branches in southern regions is still considerably lower then in the Centre-North. Therefore, apart from an increase in bank size, the consolidation of bank structures and the growth of the branch network have produced two opposite distance-related effects. There has been an increase in the average functional distance between the decision-making centres of banks and the local economies and a reduction in the average operational distance between lenders and borrowers.

\section{Bank M\&As and access to credit for small businesses}

Building on the robust empirical evidence showing the greater bank-credit dependence of small firms and the disproportionately low aptitude of large banks towards small business lending, it is quite common in the literature to warn against the risks of bank M\&As as making access to external finance harder for small firms.

Actually, the reality that emerges from empirical studies is much more complex, suggesting that the effects of bank consolidation vary significantly with the type of institutions involved. While consolidations occurring between medium-large banks or those in which large banks have incorporated a small bank usually have led to a reduction in small business lending, mergers and acquisitions involving small banks have led to a bigger share of loans to small firms and a lower start-up rate of new businesses (Berger et al. 1998; Peek and Rosengren 1998, Strahan and Weston 1998, Francis, Hasan and Wang 2008). In addition, when the acquired bank becomes part of a large multiple bank holding company, the internal capital market allows it to be more sensitive to local loan demand (Houston and James 1998). Other studies found that the likelihood of a small firm having a credit line from a large bank is proportional to the share of large banks in the market and depends on the whole structure of local credit markets, suggesting that large banks are not disadvantaged in funding opaque small borrowers (Jayaratne and Wolken 1999; Berger, Rosen and Udell 2007). Moreover, careful assessment of the effects of M\&As on small business lending should not be limited to static analysis, but it should take into account portfolio reassessment policies made by the consolidated bank and the reactions of its local 
competitors who might cover market niches no longer served by the consolidated institution (Berger et al. 1998) ${ }^{5}$.

The varied and uncertain effects of banking consolidation on small business lending are confirmed by studies analyzing the Italian experience. Using bank balance-sheet data, Focarelli, Panetta and Salleo (2002) found that mergers and acquisitions caused a significant and persistent reduction in the share of credit available to small firms, especially in the case of acquisitions and for the acquired banks. Diversely, using firm-level data, Bonaccorsi di Patti and Gobbi (2001, 2007) found that the reduction in corporate loans is only temporary, suggesting that short-run shocks due to consolidation are likely to be absorbed in the long run. Furthermore, small firms are subject to a reduction in credit availability if two of their lenders merge together, consistent with the hypothesis that small firms suffer more from increased market power, at least in the short run.

The differentiated effect of bank M\&As on the basis of market characteristics and the size of the target bank is analyzed by Sapienza (2002). She distinguishes between provinces affected by only in-market and out-of-market M\&As. Her findings suggest that: (1) the interest rate charged to continuing borrowers of small target banks is lower but the decrease is much smaller in out-ofmarket than in in-market M\&A provinces; (2) consolidation involving large targets have opposite effects, increasing the interest rate especially in in-market M\&A provinces; (3) borrowers of acquired banks have a higher probability of being dropped especially if they are small-sized and clients of small target banks.

Finally, the differentiated effects of consolidation related to the spatial distribution of credit institutions involved in M\&As is considered by Alessandrini, Croci and Zazzaro (2005) and Alessandrini, Calcagnini and Zazzaro (2008). The former found that, unlike what happens in the Centre-North, acquired banks headquartered in less developed southern regions show worse performance indicators in terms of small business lending, loan growth, bad loans and profitability than independent banks located in the same area. This is true regardless of time elapsing from acquisition and the size of the acquired bank. These findings are confirmed by Alessandrini, Calcagnini and Zazzaro (2008) who found that acquisitions involving banks in the most developed area (central and northern Italy) were dominated by a simple asset-cleaning strategy, according to which the bidder bank makes a clean sweep of all the negative net present value activities in the portfolio of the target bank without permanently changing the asset allocation of the target bank. By contrast, in the case of acquisitions of banks in the less

\footnotetext{
${ }^{5}$ Berger and Udell (2002) point out that a contraction in small business lending could depend not only on the size effect, but also on dynamic changes in the managerial and organizational strategies. However, possible "external effects" due to the increased supply of relationship credit by other local banks could reduce the contraction in credit
} 
developed southern regions by banks of the Centre-North, the asset restructuring strategy pursued by the acquiring bank led to a structural change in the portfolio of the acquired bank with a permanent reduction in loans to small firms and an increase in asset management activity. Moreover, they show that the greater the cultural distance (in terms of social capital) between the provinces where dealing partners are headquartered, the more pronounced and permanent are portfolio changes of acquired banks, while physical distance has only temporary effects. Such findings suggest that geographically diversifying acquisitions entail a comparative disadvantage in small business lending only where the corporate culture of the acquiring and acquired banks is profoundly different and that distance, rather than size, may affect bank lending policies.

\section{Branch and headquarters locations: the role of distances}

\subsection{The lender-borrower operational distance}

In spite of the advancements in communication technology and the ever-increasing use of creditscoring models, excluding a few large enterprises, the bank-firm relationship is still a local phenomenon, in Europe (and Italy) more than in the United States ${ }^{6}$. On this basis, the idea that distance from the borrower affects the bank's decisions on credit approval and conditions has gained broad consensus in the literature. In theory, how the physical proximity of a loan office to the customer acts on the lender-borrower relationship is ambiguous, with market-power and information-cost effects having to be weighed. This ambiguity is confirmed by the empirical evidence. Studies at the bank level show that the closer a firm is to its lending office the higher the interest rate paid to the bank, suggesting that physical proximity allows banks to capture their clients thanks to either transportation or information costs, (Petersen and Rajan 2002; Degryse and Ongena 2005; Agarwal and Hauswald 2008). At the same time, the probability of a bank approving a loan application or lending in a given area increases with the proximity to the customers (Breevort and Hannan 2006, Agarwal and Hauswald 2008).

At the market level, the literature on the real consequences of local banking development suggests that a larger number of banks and branches per inhabitants reduces information asymmetries and transaction costs, positively affecting the credit availability to local firms and their performance (Avery and Samolyk 2000; Bonaccorsi di Patti and Gobbi 2001; Benfratello, Schiantarelli and Sembenelli 2008). However, Alessandrini, Presbitero and Zazzaro (2008) found

availability to SMEs following consolidation, even if private information gathered thanks to relational lending is likely to get lost.

${ }^{6}$ From the Survey of Small Business Finances it results that in the US, for lines of credit (mortgage) the median distance between firm's headquarters and the lender was 3 (7) miles in 2003 and 4 (4) miles in 1993 (Breevort and Wolken 2009). From studies on single banks in Belgium and Sweden the median lender-borrower distance is 1.4 and 0.62 miles respectively (Degryse and Ongena 2005; Carling and Lundberg 2005). 
that the effects of branch density on firms' credit constraints and innovation adoption disappear to the point of insignificance .

\subsection{The headquarter-to-branch functional distance}

Economists and geographers are increasingly wondering about causes and consequences of the recent trend of agglomeration of firms' headquarters in large urban areas and the functional specialization of cities (Duranton and Puga 2005). The driving forces for clustering headquarters of large enterprises in a few well-developed urban areas are the network externalities linked to the opportunities of grabbing information on market prospects, brewing innovations, and having high-quality human resources, business services and transport facilities (Klier and Testa 2002; Strass-Kahn and Vives 2005; Bel and Fageda 2008). The location of headquarters and the geographic dispersion of the firm's structures affect corporate decision making and provide local management/employees with different incentives according to distance from the senior headquarters management. As illustrated by a recent study on a large set of publicly traded nonfinancial companies in the United States, the distance between divisions and headquarters impinges on information flows inside organizations and has a significant impact on managerial choices (Landier, Nair and Wulf 2007). In particular, they found that geographically dispersed firms, especially if operating in soft information industries, are more (less) employee(shareholder-) friendly and follow a geographic pecking order in deciding layoffs and divestitures by which remote divisions are touched before closer divisions.

The idea that the location of headquarters both reflects and determines the economic development of a region seems to fit financial industry characteristics pretty well. First, agglomeration economies are extremely important for the banking industry, where access to highskilled human resources, financial innovation, networking and information on industries' future prospects are major sources of success (Tschoegl 2000). Second, while many standardized financial services can be easily distributed at a distance, the capacity and will to meet the financial needs of local firms under fair conditions, especially in downturn periods, are strongly influenced by the proximity of headquarters and the senior management to the local economy. Drawing on the words with which Pike (2006) summarizes the reasons for the Vaux Brewery closure in the UK and effects on the city of Sunderland where it was located, a "spatially sensitive, place aware, and locally and regionally rooted financial infrastructure may be necessary but not sufficient to underpin local and regional development". This amounts to saying that financial markets do not work in a space-neutral way and that a decentralized banking system is the major channel through which local SMEs may tap their "funding gap" (Alessandrini and Zazzaro 1999; Klagge and Martin 2005). 
Therefore, in terms of the model developed by Duranton and Puga (2005), bank branches are the local plants where personal contacts with borrowers are cultivated and (hard and soft) information is collected, while loan decisions and resource allocation are increasingly shifted to centralized headquarters, producing a spatial specialization of financial functions inside each bank organization. This partition, which generates what we label headquarter-to-branch functional distance, may improve the efficiency of the bank, but it may adversely affect credit allocation to local firms in economies more distant to the bank headquarters.

The organizational diseconomies due to asymmetric distribution of information inside the bank, agency problems with loan officers and influence activities aimed at affecting the distribution of bank resources make lending long-term and to informationally opaque borrowers more costly (Palley 1997; Garicano 2000; Milbourn Shockley and Thakor 2001; Stein 2002). The point is that these organizational diseconomies, as well favouritism biases towards local economy needs, are exacerbated by headquarter-to-branch distance. In this context, the term distance reflects both physical and cultural factors. For example, it is reasonable to believe that the costs of loan reviews increase with physical distance from the bank's headquarters where loan reviewers report. Similarly, reliability of communication and trust between bank's managers and local loan officers decrease with the physical distance between them, but also with the socio-cultural distance between the geographical areas where the staff of the bank's decisional centres and local offices work and live (Cremer, Garicano and Prat 2007). In the same vein, the more physically and culturally close the bank's senior managers are to a region and the local stakeholders, the greater is the incentive to favour local firms.

A number of recent studies, encompassing different countries with banking system at different stages of development, have provided evidence on the effects of headquarter-to-branch functional distance on the bank-firm relationship. On the whole, these studies corroborate the hypothesis that functionally distant banks shy away from soft-information-based lending activities and technologies. For example, Liberti and Mian (2006), looking at the loan portfolio of a large multinational bank operating in Argentina, found that credit approvals are based on hard or soft information depending on the hierarchical level at which decisions are taken. However, they also identify a specific role played by the geographical distribution of bank offices in shaping organizational diseconomies, since they proved that the decline in the use of soft information is not constant across the ladders of bank hierarchy, but it happens suddenly between levels corresponding to loan officers working in different locations.

The pivotal role played by functional distance is confirmed by Mian (2006), who focuses on Pakistan and proves that geographic and cultural distance explains part of the differences in lending behaviour between domestic and Asian and non-Asian foreign banks. Specifically, Mian 
shows that the degree of engagement with more opaque local borrowers decreases with functional distance, with foreign banks (and especially non-Asian banks) more prudent in lending to soft information sectors of the economy.

As regards Europe, Jimenez, Salas and Saurina (2008) provide evidence that, in Spain, functionally close banks are more likely to require collateral than distant lenders. To the extent that collateral is a device used by close lenders to exploit the informational advantages of proximity and contrast the price competition of large distant banks (Inderst and Muller 2007), this finding suggests that functionally distant banks rely on hard data for loan approvals and specialize in transactional lending, while local banks specialize in lending to informationally opaque firms.

Evidence of a lending-technology specialization of banks by distance is confirmed by Mistrulli and Casolaro (2008) for Italy. Namely, the authors show that distant banks charge low interest rates and focus on transactional lending, while local banks engage in close relationship with borrowers (especially if small sized) and charge high interest rates.

\section{Banking-system-to-local-economy functional distance: evidence for Italy}

In order to investigate the spatial effects of bank consolidation and understand whether, in the era of global banking, the spatial organization of credit markets still matters for local development it is necessary to examine the behaviour of entrant, functionally distant banks net of the reactions of incumbent, functionally close banks. For example, despite the lower engagement of distant banks in soft-information-based lending, small local firms could benefit from new transactional products supplied by global banks without suffering lower access to credit simply because local banks increase relational and collateral-based lending by exploiting their informational rents (Boot and Thakor, 2000; Hauswald and Marquez 2003; Inderst and Muller 2007). To assess the net impact of these actions and reactions on local firms, a number of authors have adopted a market perspective, measuring the banking explanatory variables at the local market level ${ }^{7}$.

In this vein, we have introduced a new index of functional distance between the local banking system and the local economy as the number of local branches weighted by the headquarter-to-branch distance (Alessandrini, Presbitero and Zazzaro 2008a). More precisely, the functional distance (F-DISTANCE) of the banking system of province $j$ from the local economy can be computed as:

\footnotetext{
7 Amongst others, see Avery and Samolyk (2000), Bonaccorsi di Patti and Gobbi (2001), Collender and Shaffer (2003), Guiso, Sapienza and Zingales (2004a), Berger, Rosen and Udell (2007); Benfratello, Schiantarelli and Sembenelli (2008).
} 


$$
F-\operatorname{DISTANCE}_{j}=\frac{\sum_{b=1}^{B_{j}}\left[\text { Branches }_{b} \times \ln \left(1+D_{j{ }_{b}}\right)\right]}{\sum_{b=1}^{B_{j}} \text { Branches }_{b}},
$$

where $B_{j}$ is the number of banks operating in province $j$, Branches $b$ is the number of branches belonging to bank $b$, and $D_{j z_{b}}$ is the headquarter-to-branch physical or cultural distance. Lacking information on the exact branch spatial location, we considered the distance between the capitals of province $j$ where the branch of bank $b$ is located and province $z$ where $b$ is headquartered, assuming that banks headquartered in province $j$ are distant zero from their branches in that province. Physical distance is measured in kilometres $\left(D_{j z_{b}}=K M_{j z_{b}}\right.$, with $\left.K M_{j j_{b}}=0\right)$, while cultural distance is measured by the difference in modulus between the social capital in the branch and headquarter provinces $\left(D_{j z_{b}}=\left|S C_{j_{b}}-S C_{z_{b}}\right|\right)^{8}$.

In what follows, we discuss the effect of the functional distance of the banking system from the local economy on the bank-firm relationship, reviewing the main results from our previous research concerning credit rationing and innovation adoption, and presenting some new evidence on the firms' involvement in relational lending. In all these empirical exercises we merge credit market variables computed at the provincial level on the basis of Bank of Italy public data, with micro-level data drawn from a well-known survey on Italian manufacturing firms published every three years by the Unicredit banking group. The survey collects a large set of information on a representative sample of Italian SMEs. Besides functional distance, we control for four other credit market characteristics: (1) branch density, as a proxy of operational distance (BRANCH/POP), (2) the Herfindhal index proxying for market concentration (HHI), (3) the share of branches belonging to mutual banks, as a proxy of the degree of localism of the banking system (MUTUAL BANKS), (4) the share of branches belonging to large banks, proxying for the hierarchical complexity of the local banking system ( $L A R G E B A N K S)$.

\subsection{Credit rationing}

The first empirical question we deal with concerns the effects of the functional distance of the banking system from the local economy on firms' financing constraints. The hypothesis is that the appraisal of firms' creditworthiness requires a certain amount of soft information which could be difficult to obtain and treat by banks that are functionally distant from the local

\footnotetext{
8 Physical distances are calculated with ArcView GIS software, while social capital is measured by the average voter turnout at the 21 referenda held in Italy in 1993, 1995 and 2001 as published by the Home Department (see Alessandrini, Presbitero and Zazzaro 2008a, for more details and alternative measures of social capital).
} 
economy. In Alessandrini, Presbitero and Zazzaro (2008a, 2008b) we addressed this question both at the firm and market level. At the firm level, we found that both the probability of being credit-rationed and the sensitivity of investment to cash-flow is significantly higher for firms located in provinces where the local banking system is functionally distant. At the market level, we found that functional distance is positively correlated with the ratio between credit lines used and credit lines available (which is a proxy for credit market tightness) and negatively correlated with the ratio between overdrawn and available credit lines (which is a proxy for the flexibility of credit supply). All the adverse effects of functional distance were especially strong and significant for small firms.

In Table 2 we report the coefficients of a probit regression with instrumental variables in which the dependent variable is a dummy which is equal to one whether the firm states it is credit-rationed and zero otherwise. The model includes standard firm-specific control variables, banking market characteristics, and industry, geographic and time dummies. To take into account possible reverse causality and omitted variable problems we instrumented all the banking variables with the geographical distribution of banks and branches in 1936 and 1971. As we stated above, regression results show that increasing functional distance makes firms' access to credit more difficult, regardless of whether we compute F-DISTANCE in physical or cultural terms. Moreover, the coefficients on F-DISTANCE_KM and F-DISTANCE_SC are greater for small than for large firms and their adverse impact is especially relevant for businesses located in southern provinces'. The magnitude of these differentiated effects is statistically and economically significant: a change in the F-DISTANCE_KM indicator equal to its observed variation between 1996 and 2003 is associated with an increase in the likelihood of credit rationing of 1.8 (1.3) percentage points for small firms (the average firm) headquartered in the Centre-North, while it is 4.3 (3.5) points for the small firms (the average firm) in the South.

[Insert Table 2]

Moving on to the other local banking market characteristics, neither the number of branches per inhabitants (the operational proximity), market concentration nor the degree of localism have any statistically significant impact on the probability of credit rationing. Only the number of banks from which the firm borrows (BANK NUMBER) has a negative effect on the probability of small firms obtaining the credit demanded, consistent with the hypothesis that multiple lending discourages banks from relational lending.

In Alessandrini, Presbitero and Zazzaro (2008b) we focused on industrial districts (IDs), to investigate whether the effect of distances in credit markets is differentiated according to whether 
or not firms are part of an industrial cluster. The rationale for this hypothesis is that district firms, heavily dependent on network economies, could benefit more than isolated firms from a banking system which is functionally close to the ID. Results show that district firms are generally less credit-rationed than the isolated ones. Nonetheless, the positive effect of being located in an ID is lower in provinces where functional distance is higher and operational proximity lower, consistent with the hypothesis that bank-firm relationships in IDs rely on the specific knowledge of local economies by loan officers and on their capacity to transmit reliable soft information to the decisional centres of the bank.

\subsection{Financing Innovation}

To the extent that large banks tend to be usually more geographically dispersed, functional distance between the banking system and the local economy could capture effects due to the presence of large banks. In other words, the organisational diseconomies and the resulting disadvantages in information-intensive lending we attribute to the functional distance of the bank headquarters from the lending branches (a spatial-specific factor) could depend on the average size of banks (a characteristic pertaining to the bank as a whole, regardless of where it lends). We addressed this identification problem in Alessandrini, Presbitero and Zazzaro (2008c), where we analyzed the effects of functional distance and bank size on the firms' propensity to introduce product and process innovations ${ }^{10}$.

Specifically, we estimated an instrumental variable probit model for the likelihood of firms adopting innovations, considering jointly the effects of functional distance and of the share of branches in a province belonging to large bank groups. Moreover, we controlled for branch density and credit market concentration in the province, for standard firm characteristics and for time, industry and regional fixed effects. Once again, banking variables were instrumented with the geographical distribution of banks and branches in 1936 and 1971.

Table 3 reports our main results. First, functional distance, both in kilometric and cultural terms, is negatively associated with the probability of firms introducing innovations, while the coefficient on the market share of large banks, even if negative, is not statistically significant. Second, the discouraging effect of functional distance is greater for small firms. In Figure 4 we plot the average impact that a change from the first to the third quartile of F-DISTANCE_KM and $L A R G E B A N K S$ distributions has on the predicted propensity to innovate by firm size. In

\footnotetext{
9 Apart from small firms, the adverse effect of functional distance seems to be especially harmful for innovative firms, even after controlling for the share of branches belonging to large banks operating in the province (Alessandrini, Presbitero and Zazzaro 2008c).

10 The association between banks and firms' innovation has been at the centre of some recent studies in Italy and the US, which stresses the pivotal role of relationship lending (Atanassov, Nanda and Seru 2007; Herrera and Minetti 2007) and of the size of local banking systems (Benfratello, Schiantarelli and Sembenelli 2008).
} 
provinces where the banking system is functionally distant the predicted probability of innovation is considerably lower, being almost 15 per cent less for firms with 11-20 employees (less than 10 per cent for firms with 251-500 employees), than in provinces where the banking system is functionally close. Apart from being statistically insignificant, the adverse effect of bank size is much narrower.

\section{[Insert Table 3] \\ [Insert Figure 4]}

It is worth noting that, once we distinguish product from process innovation, functional distance is especially detrimental for the adoption of the latter type of innovation, which usually entails the acquisition of new machinery requiring lumpy investments and a great amount of external finance. By contrast, the market share of large banks is negatively associated with the probability of introducing new products which may depend on a lower amount of finance but needs a long-lasting and stable relation with banks supporting their innovative effort.

Finally, with regard to the other credit market indicators, we found that market concentration facilitates the funding of opaque borrowers/projects, while operational distance (measured by branch density) is ineffective.

\subsection{Relationship lending}

For small firms, access to credit is facilitated by stable and exclusive bank relationships (Petersen and Rajan 1994; Berger and Udell 1995), albeit at the cost of being informationally captured by the main bank (Montoriol Garriga 2006; Gambini and Zazzaro 2008). Due to agency problems with loan officers and the difficulties in processing and transferring soft information, functionally distant banks can be thought to prefer arm's length to relational lending, thereby penalising small firms. However, a greater presence of out-of-market banks in the province could drive local banks to specialize in relationship banking and invest in borrower-specific knowledge, on the whole making more frequent the use of lending technologies based on stable relationships (Boot and Thakor 2000; Hauswald and Marquez 2003; Brevoort and Hannan 2006).

Empirically, relationship lending is a complex phenomenon, difficult to measure. It includes different aspects related to the length of the relationship, the amount and variety of financial products supplied, typically proxied by the number of years since the bank-firm relationship was established, the number of lending banks, and the share of loans supplied by the main bank. Referring to the German experience, Elsas (2005) shows that the Hausbank status is associated with a great share of total debt financing, while it is less affected by the number of alternative financial suppliers and the length of the lending relationship. On this basis, in Table 4 we report 
the estimation results of a fractional logit model (Papke and Wooldridge 1996) ${ }^{11}$, in which the endogenous variable is the share of a firm's total debt held by its main bank (SHARE). Apart from the banking-system-to-local-economy functional distance (F-DISTANCE_KM), the banking variables set includes the number of banks per capita $(B A N K / P O P)$, credit market concentration, a dummy variable taking the value of 1 if the firm's main bank is a local bank headquartered in the same province and 0 otherwise (BANK PROV), and the share of local branches belonging to mutual banks. Finally, we control for firm-specific characteristics, industry, time and geographical dummies (see Table 4).

The basic specification (column 1) points out a positive correlation between functional distance and the share of firm's loans funded by the main bank, suggesting that the greater the number of branches belonging to distant banks, the higher the probability of firms engaging in relationship lending. Similarly, the positive and significant coefficients on $H H I, M U T U A L$ $B A N K S$ and $B A N K P R O V$, indicate that exclusive bank ties are more likely to be observed for firms headquartered in provinces where the credit market is more concentrated and bank localism is more diffused, and for firms whose main bank is a local bank. By contrast, the number of banks per inhabitants discourages relationship lending, consistent with the existence of winner's curse phenomena and other adverse competition effects.

[Insert Table 4]

As we noted, the positive impact of functional distance on relationship lending could be due to an indirect effect following the reaction of local banks. To investigate this possibility, in column 2 we add the interaction term between F-DISTANCE_KM and BANK PROV, finding evidence that firms located where the functional distance of the banking system from the local economy is great resort less to relationship lending. However, for firms whose main bank is a local bank, the negative effect of functional distance is overwhelmed by the more exclusive ties established with their own main bank, consistent with the idea that local banks have a competitive advantage in relationship lending that they can use when pressed by stronger competition.

The differentiated impact of functional distance and market concentration on relationship lending is confirmed in the last three specifications (columns 3-5) in which the HHI index is interacted with F-DISTANCE_KM and MUTUAL BANKS. The market concentration is beneficial for relationship banking only if the local banking system has a strong presence of branches belonging to banks headquartered outside the province. On the contrary, in provinces

\footnotetext{
11 The structure of the dependent variable, which is bounded between zero and one makes the OLS linear regression unsuitable because it cannot guarantee that the predicted values lie in the unit interval, as for binary data models. The standard solution of applying a logistic transformation to SHARE presents various drawbacks. A possible solution
} 
where local banks have a great market share and the banking system is functionally close, market concentration adversely affects the adoption of relational lending technologies. To the extent that market competition and concentration are positively correlated, these results further confirm the theoretical prediction that more competition makes relationship lending a competitive edge for banks in markets dominated by banks with a specific local dimension or whose decisional centres are close (Boot and Thakor 2000). By contrast, the argument that identifies competition as a negative determinant of relationship lending seems to prevail in provinces where loan offices are functionally distant from banks' decisional centres due to the higher switching probability of customers across banks and banks' lower capacity to profit from inter-temporal loans (Petersen and Rajan 1995 and, more generally, Boot 2000).

\section{Concluding remarks}

In this paper we examined the interrelations between global banking and local credit markets. There have been two spatial trends in banking activities during the last twenty years: the geographical agglomeration of decisional centres through mergers and acquisitions and the geographical diffusion of branch networks and distribution channels. From the point of view of local markets, these trends have produced two opposite effects in terms of distances: banks tend to be functionally more distant, but at the same time they are usually operationally more proximate to their customers.

We reviewed a wide range of empirical research and we produced some new evidence on the impact of this structural change of local banking systems on bank-firm relationships, namely, on credit availability, innovation financing, and relationship lending. The results are in part ambiguous, some times contrasting, sometimes insignificant. The uncertainty of the results is especially evident for lender-borrower operational distance. On the contrary, robust empirical evidence confirms the hypothesis that the increased headquarter-to-branch functional distance has negative effects on small and medium local firms in terms of higher probability of credit rationing, less innovation financing and reduced relationship lending.

On this basis, we can draw some conclusions on three aspects of the regional distribution of the banking systems: (1) the evolution of bank localism, (2) bank territorial strategies, (3) the strategic importance of the location of bank headquarters for regional development.

First of all, local banking structures should be diversified to satisfy a combination of local and global tasks. The local task is to meet the local needs of informationally opaque, but creditworthy borrowers, exploiting the benefits of local knowledge warranted by geographical

which does not require data adjustments and allows for direct estimation of the conditional expectation is the fractional logit model proposed by Papke and Wooldridge (1996). 
rootedness and relational embeddedness. The global task aims to make available to local operators the best solutions for allocating savings, financing investment and acquiring innovation that global credit markets offer. Since there is no single winning banking model a priori in achieving both tasks, it is important to promote a competitive equilibrium between several banks, differing in size, management and ownership structures. However, the soundness of local banking structures for boosting local development must be judged in relation to the geographical area of reference. The needs of different local systems are complex and diverse according to the level of development of their economy. They range from firm size consolidation, technological and organisational innovations, to relocation investments and to problems of generational and professional turnover. Such needs can no longer be accomplished only by small local banks. At the same time, the variety of regional development problems limits the contribution of efficiency made by large banking organisations distributing standardised financial instruments. The recognition of different local productive systems leads to a flexible approach with a mix of relationship activities, that offer bespoke products and services (specialised bank), and transactions activities, that offer standardised products and services (network bank).

The second issue concerns bank territorial strategy. Given the existence of economic regional disparities, the importance in bank strategies of being geographically rooted cannot be generalised. In more advanced regions, bank branch density is greater and small firms are less penalised in credit conditions (rates, availability, collaterals). In peripheral regions, geographical rootedness can be more of a constraint than an opportunity, generating a local-local vicious circle which can be broken by opening up local banking markets to competition from out-of-market banks and the acquisition of local inefficient banks.

These local development needs must be met not only by local independent banks but also by large banking groups. It is no longer a matter of large or small size, but rather of strategic sensitivity. Local independent banks, selected by banking competition, can exploit their advantages of contextual knowledge of the local environment provided that they invest in human capital and in strategic alliances in order to be connected to global financial circuits and to extend the range of financial products and services to their local customers. On the other hand, large bank groups may attenuate the adverse effects of their greater functional distances with strategies of organisational decentralisation and flexible adaptation to the various environmental contexts. They should grade financial innovations to the specific requirements of each system: the greater the development gaps to be filled and the endowment of small firms to assist, the more localoriented such requirements should be. In this diversified field. It is important to be able to exploit the advantages of relational and functional proximities. This holds not only for banks, but 
also for venture capital activities, which require an intensive long-term form of relationship financing.

The third aspect concerns the strategic importance of being able to count at least on a strong banking competitor with its "thinking head" in the region. The first reason lies in the consideration that, in addition to the positive effects on bank performance, functional proximity produces important externalities for the accumulation of human, social and institutional capital. Usually, the most qualified and specialised human resources (managers, directors, professionals, financial analysts) reside in regions where banking decisional centres are located. Externalities of this type affect entrepreneurship, as well as social and institutional capital. Indeed, the concentration of bank decisional centres through mergers and acquisitions leads to a change in the functional hierarchy between central and peripheral regions whose consequences need close scrutiny. The second reason is that a significant presence of headquartered banks helps to maintain economic centrality in the region. In this case, outside banks have to consider the specific needs of the local area if they want to erode the advantages that headquartered banks have in terms of regional knowledge. It is not a question of abandoning the selective process in the free market of property rights, which should not be impeded. What is instead desirable is also to promote the entrepreneurial and managerial skills of local banks, selected by competitive pressures, as a vital agent of economic and social development in industrial districts and, in general, in any local production system. Finally, local banking structures that give strategic priority to the specific needs of local firms and regional development are relatively less open to standardized financial instruments, transferred through globalized circuits. Consequently the regions that benefit from this strategic centrality are less exposed to outside risks of financial contagion in periods of greater worldwide financial instability, as we are experiencing in this first decade of the new century.

\section{References}

Agarwal, S. and Hauswald, R.B.H. 2008. Distance and Private Information in Lending, unpublished working paper, Federal Reserve Bank of Chicago and American University.

Alessandrini, P., Calcagnini, G. and Zazzaro, A. 2008. Asset restructuring strategies in bank acquisitions: Does distance between dealing partners matter?, Journal of Banking and Finance, forthcoming.

Alessandrini, P., Croci, M. and Zazzaro, A. 2005. The geography of banking power: the role of functional distance, BNL Quarterly Review, 235, 129-67. 
Alessandrini, P., Fratianni, M. and Zazzaro, A. 2009. The Changing Geography of Banking and Finance, Springer, forthcoming.

Alessandrini, P., Papi, L. and Zazzaro, A. 2003. Banks, regions and development, BNL Quarterly Review, 224, 23-55.

Alessandrini, P., Presbitero, A.F. and Zazzaro, A. 2008a. Banks, Distances and Firms' Financing Constraints, Review of Finance, forthcoming.

Alessandrini, P., Presbitero, A.F. and Zazzaro, A. 2008b. Banche e imprese nei distretti industriali, in A. Zazzaro (ed.), I vincoli finanziari alla crescita delle imprese. Carocci, Rome.

Alessandrini, P., Presbitero, A.F. and Zazzaro, A. 2008c. Bank size or distance: What hampers innovation adoption by SMEs?, unpublished working paper, Università Politecnica delle Marche.

Alessandrini, P. and Zazzaro, A. 1999. A 'Possibilist' Approach to Local Financial Systems and Regional Development: the Italian Experience, in R. Martin (ed), Money and Space Economy, Wiley \& Sons, New York.

Atanassov, J., Nanda, V.K. and Seru, A. 2007. Finance and Innovation: The Case of Publicly Traded Firms, unpublished working paper.

Avery, R.B. and Samolyk K. 2000. Bank Consolidation and the Provision of Banking Services: Small Commercial Loans, Journal of Financial Services Research, 25, 291-325.

Bel, G. and Fageda, X. 2008. Getting There Fast: Globalization, Intercontinental Flights and Location of Headquarters, Journal of Economic Geography, 8, 471-95.

BCE 2004. EU Banking Structures, European Central Bank, Frankfurt.

BCE 2007. EU Banking Structures, European Central Bank, Frankfurt.

Benfratello, L., Schiantarelli, F. and Sembenelli, A. 2008. Banks and Innovation: Microeconometric Evidence on Italian Firms, Journal of Financial Economics, forthcoming.

Berger, A.N., Miller, N.H., Petersen, M.A., Rajan, R.G. and Stein, J.C. 2005. Does function follow organizational form? Evidence from the lending practices of large and small banks, Journal of Financial Economics, 76, 237-69.

Berger, A.N., Rosen and Udell, G.F. 2007. Does market size structure affect competition? The case of small business lending, Journal of Banking and Finance, 31, 11-33.

Berger, A.N., Saunders, A., Scalise, J.M. and Udell, G.F. 1998. The effects of bank mergers and acquisitions on small business lending, Journal of Financial Economics, 50, 187-229.

Berger, A.N. and Udell, G.F. 1995. Relationship Lending and Lines of Credit in Small Firms Finance, Journal of Business, 3, 351-81.

Berger, A.N. and Udell, G.F. 2002. Small business credit availability and relationship lending: The importance of bank organizational structure, Economic Journal, 112, F32-F53. 
Bonaccorsi di Patti, E. and Gobbi, G. 2001. The changing structure of local credit markets: Are small business special?, Journal of Banking and Finance, 25, 2209-2237.

Bonaccorsi di Patti, E. and Gobbi, G. 2007. Winners or losers? The effects of banking consolidation on corporate borrowers, Journal of Finance, 62, 669-95.

Boot, A.W.A. 2000. Relationship Lending: What Do We Know?, Journal of Financial Intermediation, $9,7-25$.

Boot, A.W.A. and Thakor, A.V. 2000. Can relationship banking survive competition?, Journal of Finance, 55, 679-713.

Branson, W.H. 1990. Financial Market Integration, Macroeconomic Policy, and the EMS, in C. Bliss and J. B. de Macedo (eds), Unity with Diversity in the European Community: The Community's Southern Frontier, Cambridge University Press.

Brevoort, K.B. and Hannan, T.H. 2006. Commercial lending and distance: evidence from Community Reinvestment Act data, Journal of Money Credit and Banking, 38, 1991-2012.

Brevoort, K.B. and Wolken , J.D. 2009. Does Distance Matter in Banking?, in P. Alessandrini, M. Fratianni and A. Zazzaro (eds), The Changing Geography of Banking and Finance, Springer, forthcoming.

Buch, C.M. and DeLong, G.L. 2008. Banking Globalization: International Consolidation and Mergers in Banking, IAW Discussion Paper, 38.

Carling, K. and Lundberg, S. 2005. Asymmetric information and distance: an empirical assessment of geographical credit rationing, Journal of Economics and Business, 57, 39-59.

Chick, V. and Dow, S. 1988. A Post-Keynesian Perspective on the Relation Between Banking and Regional Development, in P. Arestis (ed.), Post-Keynesian Monetary Economics - New Approaches to Financial Modelling, Edward Elgar, Aldershot, pp. 219-250.

Collender, R.N. and Shaffer, S. 2003. Local bank ownership, deposit control, market structure, and economic growth, Journal of Banking and Finance, 27, 27-57.

Craig, S.G. and Hardee, P. 2007. The impact of bank consolidation on small business credit availability, Journal of Banking and Finance, 31, 1237-63.

Cremer, J., Garicano, L. and Prat, A. 2007. Language and the Theory of the Firm, The Quarterly Journal of Economics, 122, 373-407.

Degryse, H. and Ongena, S. 2005. Distance, lending relationship, and competition, Journal of Finance, 60, 231-266.

Dermine, J. 2006. European Banking Integration: Don't Put the Cart Before the Horse, Financial Markets, Institutions \& Instruments, 15, 57-106.

De Young, R., Klier, T. and McMillen, D.P. 2004. The Changing Geography of the US Banking Industry, The Industrial Geographer, 2(1), 29-48. 
Duranton, G. and Puga, D. 2005. From sectoral to functional urban specialization, Journal of Urban Economics, 57, 343-370.

Elsas, R. 2005. Empirical Determinants of Relationship Lending, Journal of Financial Intermediation, $14,32-57$.

Focarelli, D., Panetta, F. and Salleo, C. 2002. Why do banks merge?, Journal of Money, Credit and Banking, 34, 1047-1066.

Francis, B., Hasan, I. and Wang, H. 2008. Bank consolidation and new business formation, Journal of Banking and Finance, 32, 1598-612.

Gambini, A. and Zazzaro, A. 2008. Who Captures Who? Long-lasting Bank Relationships and Firms' Growth, unpublished working paper, Università Politecnica delle Marche.

Garicano, L. 2000. Hierarchies and the Organization of Knowledge in Production, The Journal of Political Economy, 108, 874-904.

Guiso, L., Sapienza, P. and Zingales, L. 2004. Does local financial development matter?, The Quarterly Journal of Economics, 119, 929-969.

Hauswald, R.B.H. and Marquez, R. 2003. Information technology and financial services competition, The Review of Financial Studies, 16, 921-948.

Houston, J.F and James, C. 1998. Do Bank Internal Capital Markets Promote Lending?, Journal of Banking and Finance, 22, 899-918.

Inderst, R. and Muller, H.M. 2007. A lender-based theory of collateral, Journal of Financial Economics, 84, 826-859.

Jayaratne, J. and Wolken, J. 1999. How important are small banks to small business lending?: New evidence from a survey of small firms, Journal of Banking and Finance 23, 427-458.

Jimenez, G., Salas-Fumas, V. and Saurina, J. 2008. Organizational Distance and Use of Collateral for Business Loans, Journal of Banking and Finance, forthcoming.

Klagge, B. and Martin, R. 2005. Decentralized versus Centralized Financial Systems: Is There a Case for Local Capital Markets?, Journal of Economic Geography, 5(4), 387-421.

Klier, T. and Testa, W. 2002. Location trends of large company headquarters during the 1990s, Economic Perspectives, Q II, 12-26.

Landier, A., Nair, V.B. and Wulf, J. 2007. Trade-offs in Staying Close: Corporate Decision Making and Geographic Dispersion, Review of Financial Studies, forthcoming.

Liberti, J. and Mian, A. 2008. Estimating the Effect of Hierarchies on Information Use, Review of Financial Studies, forthcoming

Martin, R. 1994, Stateless monies, global financial integration and national economic autonomy: the end of geography?, in S.Corbridge, R.Martin and N.Thrift (eds), Money, Space and Power, Blackwell Publishers, Oxford, chapter 11, pp. 253-278. 
Mian, A. 2006. Distance constraints: The limits of foreign lending in poor economies, Journal of Finance, 61, 1465-505.

Milbourn, T.T., Shockley, R.L. and Thakor, A.V. 2001. Managerial Career Concerns and Investments in Information, RAND Journal of Economics, 32, 334-51.

Montoriol Garriga, J. 2006. The effect of relationship lending on firm performance, unpublished working paper, Universitat Autonoma de Barcelona.

O’Brien, R. 1992. Global Financial Integration: The End of Geography New York: Council of Foreign Relations Press.

Palley, T.L. 1997. Managerial turnover and the theory of short-termism, Journal of Economic Behavior and Organization, 32, 547-557.

Papke, L.E. and Wooldridge, J.M. 1996. Econometric Methods for Fractional Response Variables with an Application to 401(k) Plan Participation Rates, Journal of Applied Econometrics, 11, 619-32.

Peek, J. abd Rosengren, E.S. 1998. Bank consolidation and small business lending: It's not just bank size that matters, Journal of Banking and Finance, 22, 799-819.

Petersen, M.A. and Rajan, R.G. 1994.The benefits of lending relationships: Evidence from small business data, The Journal of Finance, 49, 3-37.

Petersen, M.A. and Rajan, R.G. 1995. The effect of credit market competition on lending relationships, The Quarterly Journal of Economics, 110, 407-443.

Petersen, M.A. and Rajan, R.G. 2002. Does distance still matter? The information revolution in small business lending, The Journal of Finance, 57, 2533-2570.

Pozzolo, A.F. 2009. Cross-border Mergers and Acquisitions: Causes, Consequences and Recent Trends, in P. Alessandrini, M. Fratianni and A. Zazzaro (eds), The Changing Geography of Banking and Finance, Springer, forthcoming.

Pike, A. 2006. 'Shareholder value' versus the regions: the closure of the Vaux Brewery in Sunderland, Journal of Economic Geography 6, 201-22.

Rajan, R.G. 1992. Insiders and outsiders: The choice between informed and arm's-length debt, Journal of Finance, 47, 1367-400.

Sapienza, P. 2002. The effects of banking mergers on loan contracts, The Journal of Finance, 57, 329-67.

Stein, J.C. 2002. Information production and capital allocation: Decentralized versus hierarchical firms, The Journal of Finance, 57, 1891-921.

Strahan, P.E. and Weston, J.P. 1998. Small business lending and the changing structure of the banking industry, Journal of Banking and Finance, 22, 821-45. 
Strass-Kahn, V. and Vives, X. 2005. Why and Where do Headquarters Move? CEPR Discussion Papers, 5070.

Tschoegl, A.E. 2000. International Banking Centers, Geography, and Foreign Banks, Financial Markets, Institutions \& Instruments, 9, 1-32.

Udell, G.F. 2009. Innovation, Organizations and Small Business Lending, in P. Alessandrini, M. Fratianni and A. Zazzaro (eds), The Changing Geography of Banking and Finance, Springer, forthcoming. 
Figure 1: The size of banks and banking industry in Europe.
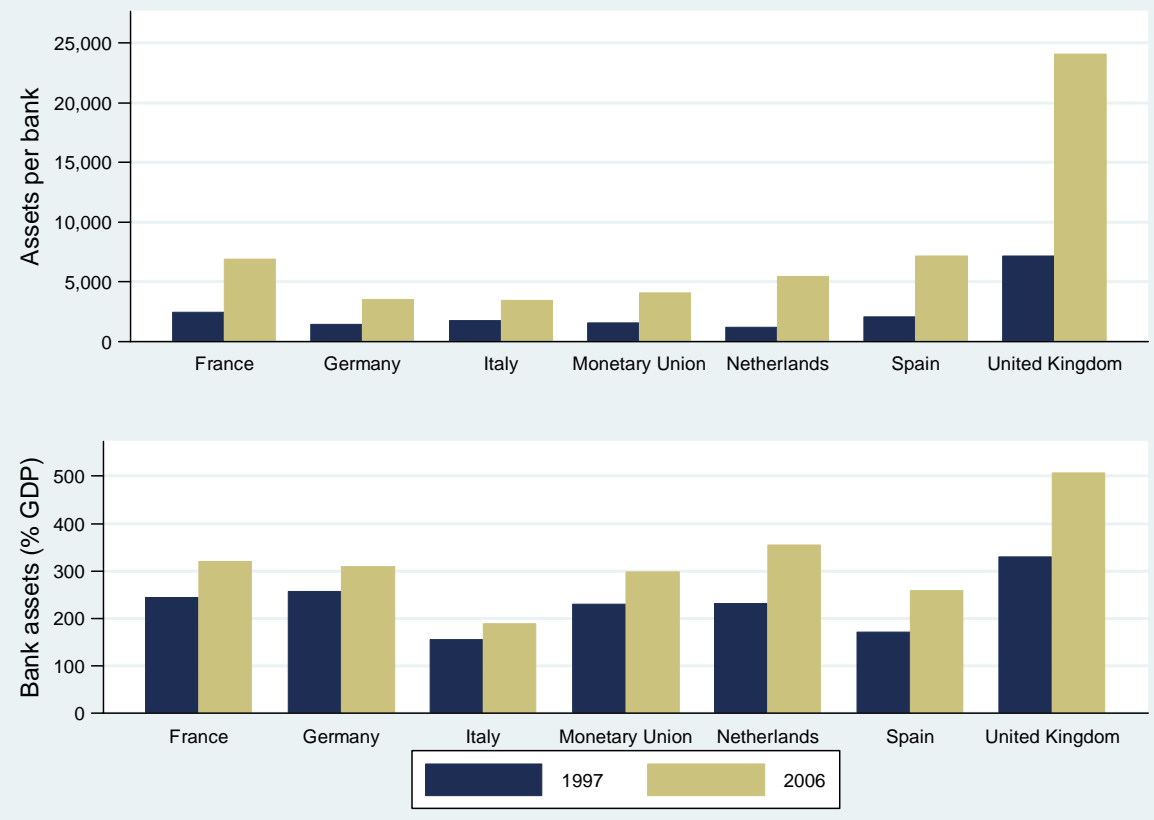

Source: Elaboration on BCE data (EU Banking Structure 2004, 2007). 
Figure 2: Branch density and banking competition in Europe.

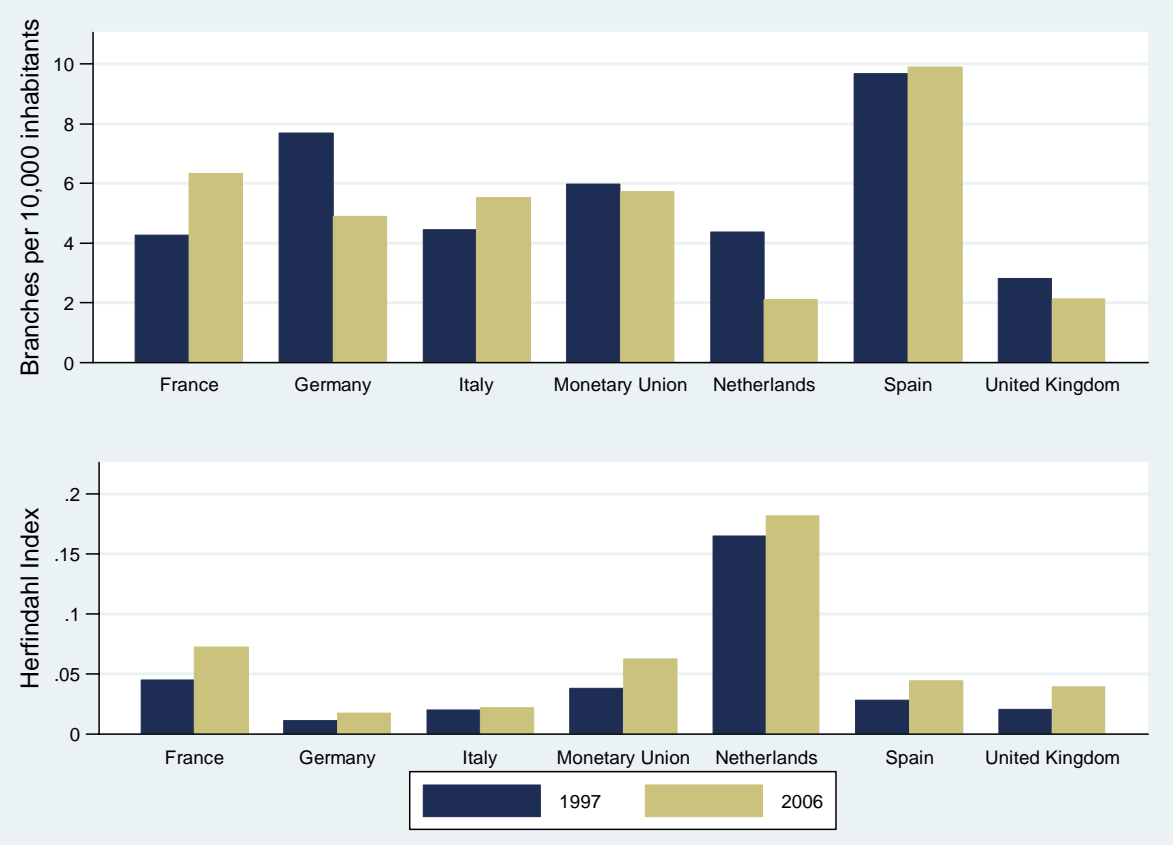

Source: Elaboration on BCE data (EU Banking Structure 2004, 2007) 
Figure 3: The presence of foreign banks in Europe.

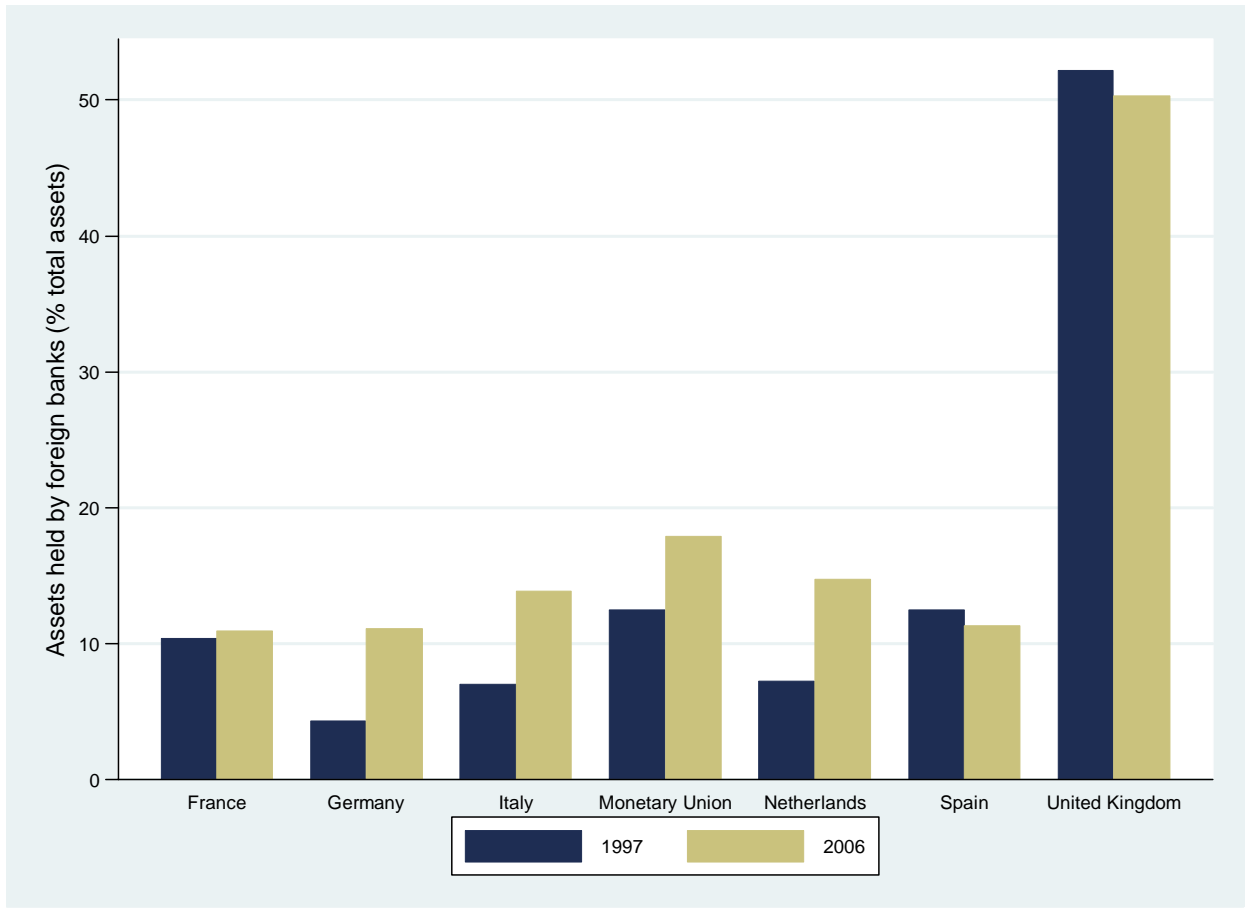

Source: Elaboration on BCE data (EU Banking Structure 2004, 2007) 
Figure 4: Changes in predicted probability due to variation in functional distance and bank size on innovation adoption.

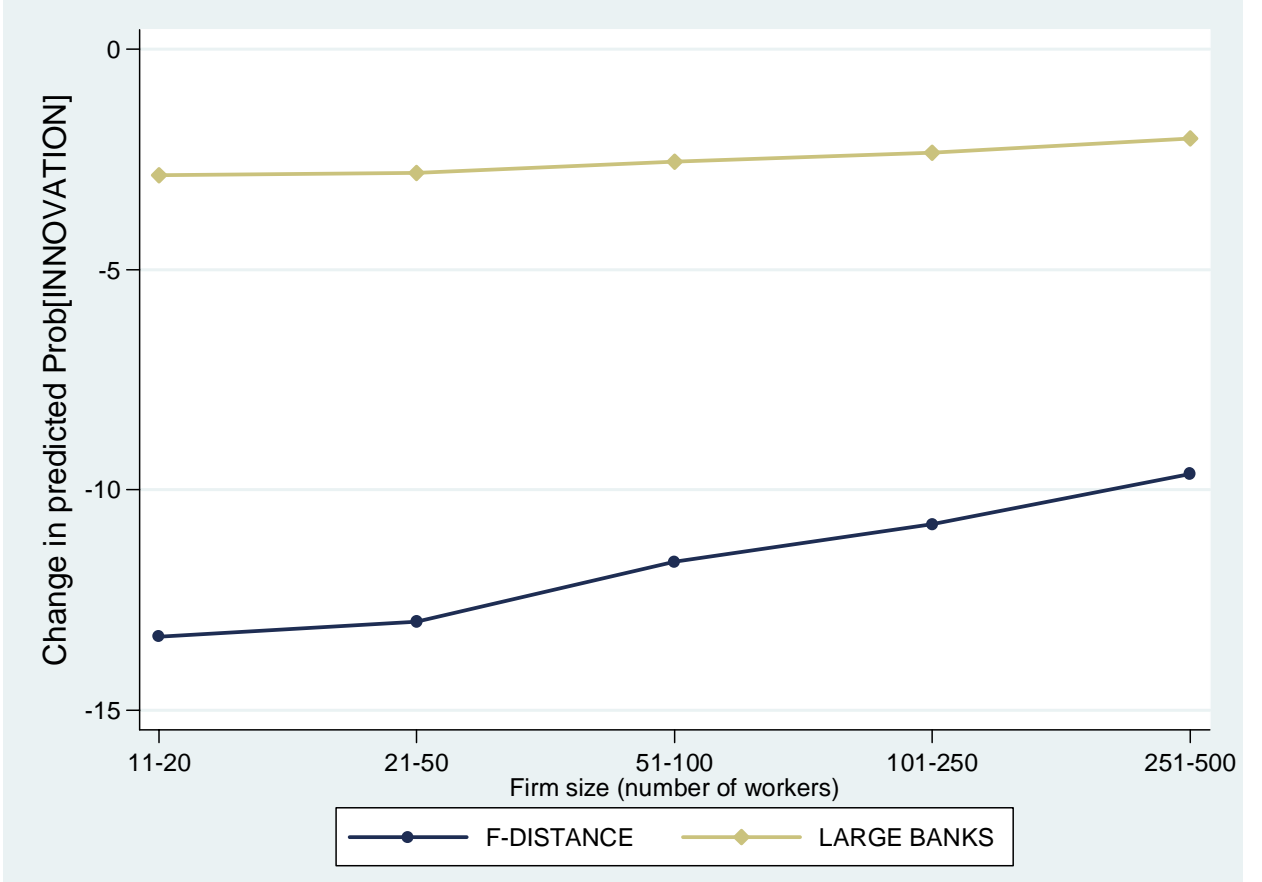

Notes: The diagram plots the effects of a variation from the first to the third quartile of F-DISTANCE and LARGE BANKS on Prob[INNOVATION], based on the estimates of column 1 of Table 3, by firm size. 
Table 1: Number of banks in Italy, Centre-North and South.

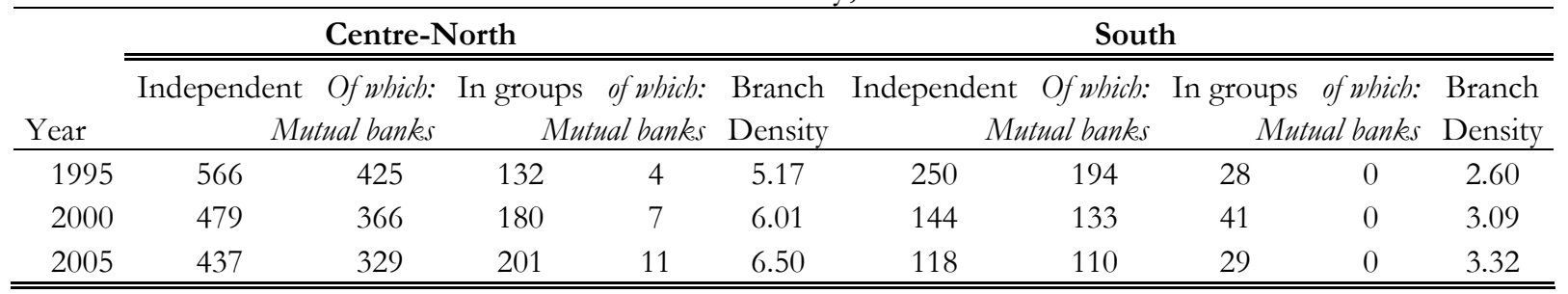

Notes: Elaboration on Bank of Italy and ISTAT data. Branch density is measured by the number of bank branches per 10,000 inhabitants. 
Table 2: Functional distance and credit constraints

\begin{tabular}{|c|c|c|c|c|c|c|}
\hline \multirow{2}{*}{$\begin{array}{l}\text { Dep Var: Prob[RAZ] } \\
\text { F-DISTANCE_KM }\end{array}$} & \multicolumn{2}{|c|}{ Whole sample } & \multirow{3}{*}{$\begin{array}{l}\text { SMALL } \\
0.211^{* *} \\
{[0.083]}\end{array}$} & \multirow{3}{*}{$\begin{array}{c}\text { LARGE } \\
0.166^{*} \\
{[0.085]}\end{array}$} & \multirow[t]{2}{*}{ SMALL } & \multirow[t]{2}{*}{ LARGE } \\
\hline & $0.169 * * *$ & & & & & \\
\hline & {$[0.057]$} & & & & & \\
\hline \multirow[t]{2}{*}{ F-DISTANCE_SC } & & $0.402^{* * *}$ & & & $0.482^{* * *}$ & $0.379 *$ \\
\hline & & {$[0.128]$} & & & {$[0.175]$} & {$[0.198]$} \\
\hline \multirow[t]{2}{*}{$B R A N C H / P O P$} & 0.046 & -0.038 & 0.134 & -0.045 & 0.028 & -0.131 \\
\hline & {$[0.072]$} & {$[0.056]$} & {$[0.106]$} & {$[0.101]$} & {$[0.078]$} & {$[0.083]$} \\
\hline \multirow[t]{2}{*}{ MUTUAL BANKS } & 0.002 & 0.007 & -0.004 & 0.008 & 0.002 & 0.013 \\
\hline & {$[0.006]$} & {$[0.005]$} & {$[0.008]$} & [0.009] & {$[0.007]$} & {$[0.008]$} \\
\hline \multirow[t]{2}{*}{$H H I$} & -0.121 & -0.091 & -0.168 & -0.061 & -0.131 & -0.029 \\
\hline & {$[0.076]$} & {$[0.072]$} & {$[0.103]$} & {$[0.122]$} & {$[0.095]$} & {$[0.119]$} \\
\hline \multirow[t]{2}{*}{ BANK NUMBER } & $-0.112^{*}$ & -0.089 & $-0.232^{* *}$ & 0.060 & $-0.178^{* *}$ & 0.058 \\
\hline & {$[0.063]$} & {$[0.060]$} & {$[0.098]$} & {$[0.069]$} & {$[0.087]$} & {$[0.069]$} \\
\hline \multicolumn{7}{|c|}{ Estimated effect on Prob $[\mathrm{R} A T]$ due to a change in $\mathrm{FD}$ : } \\
\hline \multirow{3}{*}{$\begin{array}{l}\text { from } 25^{\circ} \text { to } 75^{\circ} \text { percentile, Italy } \\
\text { from } 1996 \text { to } 2003 \text {, Centre-North } \\
\text { from } 1996 \text { to } 2003 \text {, South }\end{array}$} & 4.87 & 4.02 & 6.68 & 4.13 & 5.06 & 2.95 \\
\hline & 1.34 & 1.74 & 1.81 & 1.14 & 2.22 & 1.46 \\
\hline & 3.54 & 4.70 & 4.33 & 3.36 & 5.59 & 4.25 \\
\hline
\end{tabular}

Notes: * significant at $10 \%$; ** significant at 5\%; *** significant at $1 \%$. Robust standard errors in brackets. Estimation of a probit model with instrumental variable in which the dependent variable is the probability of a firm being credit rationed. The sample is made by 7,844 firms interviewed in the 7th, 8th and 9th Survey of Manufacturing Firms published by UniCredit. F-DISTANCE_KM is the provincial functional distance measured in kilometres, while F-DISTANCE_SC is measured in terms of differences in social capital. BRANCH/POP measures operational proximity as the number of branches per 10,000 inhabitants in the province. MUTUAL BANKS is the share of branches held by Mutual Banks on total branches in the province. HHI is the logarithm of the HerfindahlHirschman Index calculated on the number of branches in the province. BANK NUMBER is the number of banks with which the firm does business. All these variables are taken as endogenous. As instruments for these variables, we include a measure of F-DISTANCE_KM in 1971, BRANCH/POP in 1936 and 1971, HHI in 1971, MUTUAL $B A N K S$ in 1936 and 1971, the share of branches held by large banks in 1936 and 1971, the average number of new branches held by incumbent and entrant banks in the province over the period 1980-1985, the average ratio of bank debt over total assets at industry level (Ateco, 2 digit) over the period 1995-2003. The firm-level exogenous control variables set includes firm size, the share of employees working in $R \& D$, the return on investment, the debt-equity ratio and a dummy equal to one if the firm and its main bank are headquartered in the same province and zero otherwise. Geographic, industry and time dummies are included. SMALL is the sub-sample of firms employing 11-50 workers, while LARGE refers to firms with more than 50 employees. For more information refer to Alessandrini, Presbitero and Zazzaro (2008a). 
Table 3: Functional Distance and Innovation

\begin{tabular}{|c|c|c|c|c|c|c|}
\hline \multirow[t]{2}{*}{ Dep. Variable: } & \multicolumn{2}{|c|}{ Prob[INNOVATION] } & \multicolumn{2}{|c|}{ Prob[PROCESS] } & \multicolumn{2}{|c|}{ Prob[PRODUCT] } \\
\hline & $(1)$ & $(2)$ & $(3)$ & $(4)$ & $(5)$ & $(6)$ \\
\hline \multirow[t]{2}{*}{$\overline{F-D I S T A N C E \_K M}$} & $-0.244 * *$ & & $-0.230 * *$ & & -0.171 & \\
\hline & {$[0.100]$} & & {$[0.096]$} & & {$[0.106]$} & \\
\hline \multirow[t]{2}{*}{ F-DISTANCE_SC } & & $-0.601 * *$ & & -0.345 & & -0.403 \\
\hline & & {$[0.236]$} & & {$[0.224]$} & & {$[0.257]$} \\
\hline \multirow[t]{2}{*}{ LARGE BANKS } & -0.004 & -0.009 & 0.001 & 0.000 & $-0.016^{* * *}$ & $-0.019 * * *$ \\
\hline & {$[0.005]$} & {$[0.007]$} & {$[0.005]$} & {$[0.006]$} & {$[0.006]$} & {$[0.007]$} \\
\hline \multirow[t]{2}{*}{$B R A N C H / P O P$} & -0.125 & -0.092 & 0.064 & 0.185 & $-0.328^{* *}$ & $-0.297 * *$ \\
\hline & {$[0.142]$} & {$[0.130]$} & {$[0.135]$} & [0.119] & [0.154] & {$[0.142]$} \\
\hline \multirow[t]{2}{*}{$H H I$} & $0.620^{* *}$ & $0.373^{*}$ & $0.614^{* *}$ & 0.277 & 0.361 & 0.184 \\
\hline & {$[0.282]$} & {$[0.203]$} & {$[0.259]$} & {$[0.185]$} & {$[0.298]$} & {$[0.217]$} \\
\hline
\end{tabular}

Notes: $*$ significant at $10 \%$; ** significant at $5 \%$; *** significant at $1 \%$. Robust standard errors in brackets. Estimation of a probit model with instrumental variable in which the dependent variable is the probability of a firm adopting a process and/or product innovation (columns 1-2), a process innovation (columns 3-4) or a product innovation (columns 5-6). The sample is made by 7,175 (7,603 in columns 3-4) firms interviewed in the 7th, 8th and 9th Survey of Manufacturing Firms published by UniCredit. F-DISTANCE_KM is the provincial functional distance measured in kilometres, while F-DISTANCE_SC is measured in terms of differences in social capital. LARGE $B A N K S$ is computed by the ratio of branches owned by large banks (total assets of at least 50 million Euros computed at 2003 prices) to the total number of branches operating in each province. BRANCH/POP measures operational proximity as number of branches per 10,000 inhabitants in the province. HHI is the HerfindahlHirschman Index calculated on the number of branches in the province. All these variables are taken as endogenous. As instruments for these variables, we include the share of branches owned by mutual banks in 1936, the share of branches owned by saving banks in 1936, the share of branches owned by large banks in 1936, F-DISTANCE_KM in 1971 and $B R A N C H / P O P$ in 1936. The firm-level exogenous control variables set includes firm size, the return on investment, the debt-equity ratio, $\mathrm{R} \& \mathrm{D}$ intensity, the number of banks from which the firm borrows and a dummy for firms exporting a share of their sales. Geographic, industry and time dummies are included. For more information refer to Alessandrini, Presbitero and Zazzaro (2008c). 
Table 4: Functional distance and relationship lending

\begin{tabular}{|c|c|c|c|c|c|}
\hline Dep Var: $S H A R E$ & (1) & $(2)$ & (3) & (4) & (5) \\
\hline \multirow[t]{2}{*}{ F-DISTANCE_KM } & $0.018^{*}$ & $-0.004 * *$ & $-0.043 * * *$ & 0.018 & $-0.018^{* * *}$ \\
\hline & {$[0.011]$} & {$[0.002]$} & [0.012] & {$[0.013]$} & {$[0.001]$} \\
\hline \multirow[t]{2}{*}{$B A N K S / P O P$} & $-0.120^{* *}$ & $-0.122^{* *}$ & $-0.106^{*}$ & $-0.131 * *$ & $-0.121 * *$ \\
\hline & {$[0.049]$} & {$[0.050]$} & {$[0.061]$} & {$[0.060]$} & {$[0.061]$} \\
\hline \multirow[t]{2}{*}{$H H I$} & $0.040^{* * *}$ & $0.043^{* * *}$ & $-0.104^{* * *}$ & $0.078^{* * *}$ & -0.014 \\
\hline & {$[0.014]$} & {$[0.014]$} & {$[0.003]$} & {$[0.015]$} & [0.039] \\
\hline \multirow[t]{2}{*}{ MUTUAL BANKS } & $0.004^{* * *}$ & $0.004 * * *$ & $0.002^{* * *}$ & $0.009 * * *$ & $0.007 * * *$ \\
\hline & {$[0.001]$} & {$[0.001]$} & {$[0.001]$} & {$[0.002]$} & {$[0.003]$} \\
\hline \multirow[t]{2}{*}{$B A N K \operatorname{PROV}(0,1)$} & $0.024 * * *$ & $-0.087^{*}$ & $0.025^{* * *}$ & $0.026 * * *$ & $0.026^{* * *}$ \\
\hline & {$[0.004]$} & {$[0.049]$} & {$[0.004]$} & {$[0.006]$} & {$[0.006]$} \\
\hline \multirow[t]{2}{*}{$B A N K$ PROV $\times F$-DISTANCE_KM } & & $0.041 * *$ & & & \\
\hline & & {$[0.017]$} & & & \\
\hline \multirow[t]{2}{*}{$H H I \times F-D I S T A N C E \_K M$} & & & $0.042^{* * *}$ & & $0.025^{* *}$ \\
\hline & & & {$[0.001]$} & & {$[0.010]$} \\
\hline \multirow[t]{2}{*}{$H H I \times M U T U A L B A N K S$} & & & & $-0.007 * * *$ & $-0.005^{* *}$ \\
\hline & & & & {$[0.002]$} & {$[0.002]$} \\
\hline
\end{tabular}

Notes: $*$ significant at $10 \%$; ** significant at $5 \%$; ** significant at $1 \%$. Robust standard errors in brackets. Estimation of a fractional logit model in which the dependent variable (SHARE) is the share of banking credit supplied to the firm by its main bank. The sample is made by 4,390 firms interviewed in the 8th and 9th Survey of Manufacturing Firms published by UniCredit. F-DISTANCE_KM is the provincial functional distance measured in kilometres. $B A N K S / P O P$ is number of banks per 10,000 inhabitants in the province. MUTUAL BANKS is the share of branches held by Mutual Banks on total branches in the province. HHI is the Herfindahl-Hirschman Index calculated on the number of branches in the province. BANK PROV is a dummy equal to one if the firm and its main bank are headquartered in the same province and zero otherwise. The firm-level control variables set includes firm size, age, return on assets, and a dummy for innovative firms. Geographic, industry and time dummies are included. 